Research Article

\title{
Identification of TENORM in Zirconium Oxychloride with Gamma Spectrometry
}

\author{
Kharistya Rozana ${ }^{1, *}$, Devi Swasti Prabasiwi ${ }^{1}$, Dewi Puspa Ariany ${ }^{1}$ \\ ${ }^{1}$ Pusat Sains dan Teknologi Akselerator - BATAN Yogyakarta \\ *Corresponding author: kharistya.rozana@batan.go.id
}

Received: 22 January 2021; Accepted: 4 April 2021; Published: 15 April 2021

\begin{abstract}
Gamma spectrometer used to determine the type and activity of gamma emitting radionuclides, such as the measurement of TENORM (Th-232, U-238, Ra-26 dan K-40) in the zirconium oxychloride or environmental radioactivity. This research was carried out to know each the TENORM on the zirconium oxychloride $\left(\mathrm{ZrOCl}_{2} .8 \mathrm{H}_{2} \mathrm{O}\right)$ which accommodation of environment data the radioactivity in draft job safety about the workers. Zirconium oxychloride is a result of chloride acid leaching process from sodium zirconate, containing uranium and thorium, so that it has the potential for contamination and increase the radiation exposure. The instrument used for counting by HPGe detector and the spectrum were analyzed further using software Genie 2000. Mean measured activity concentrations (radioactivity) of U-238, Th-232, Ra-226 and K-40 respectively were $13.43 \pm 0.876 \mathrm{~Bq} / \mathrm{kg}, 12.040 \pm 1.483 \mathrm{~Bq} / \mathrm{kg}$, $11.400 \pm 0.582 \mathrm{~Bq} / \mathrm{kg}$ dan $32.940 \pm 3.270 \mathrm{~Bq} / \mathrm{kg}$.
\end{abstract}

Keywords: TENORM, radioactivity, zirconium oxychloride.

\section{Introduction}

Industries whose basic activities are processing activities and services of raw materials derived from the earth with a large scale crossed with the peak of natural radionuclide during the process, various natural radionuclides contained in the earth's skin rocks will be mobilized so as to form a by-product of radioactive-based materials $[1,2]$. Naturally zirconium sand mining material that has a brownish white color, non magnetic, non conductor, and contains NORM (Naturally Occurring Radioactive Material). This sand is very cheap and easy for which everywhere is the mining material that is on the surface. This material is processed further will add selling value and also have a very strategic role in various industries. In the nuclear industry, this material when combined with other metals (Zircalloy) then this alloy will be able to be done as a fuel cladding of nuclear reactors and many become large corrosion-resistant materials [3]. In the nuclear industry, this material can be processed into zirconia or in advanced ceramic materials due to its high strength and very high melting point $\left(2700^{\circ} \mathrm{C}\right)[6,7]$.

In Indonesia, zircon mineral sources in addition to obtained from Bangka, can also be obtained from Kalimantan. Zircon minerals will have bright prospects as the main source of zirconia if the material can be processed appropriately. Zircon sand when processed into zircon oxytoc chloride $\left(\mathrm{ZrOCl}_{2} .8 \mathrm{H}_{2} \mathrm{O}\right)$ and continued into zirconia, allowing each stage of the process will produce products containing TENORM. The existence of TENORM can be known by detecting the content of uranium, thorium, radium and radon and its decay $[2,3]$.

A previously research of identification TENORM in zircon sand processing at a Typical Chinese Enterprise was carried out in 2019 by Shoulong [3]. In China, the composition of monazite in zircon sand is rich in radionuclides, such as uranium, thorium and radium. This makes radiation a safety issue in the production of zirconium products. The monazite in zircon sand can be separated by the physical method because of its weak magnetic characteristic. However, the naturally-occurring radioactive materials in zircon sand are transferred and enriched with the chemical separation process, and discharged into the environment in the form of wastewater or solid waste. Therefore, the radiation issues mainly occur in the zirconium oxychloride production process, resulting in a potential radiation health hazard to workers in zirconium oxychloride production enterprises $[3,4]$.

A research of assesment of the radiological impacts of zircon sand processing in the North-Eastern part of Italy have been conducted in 2005 using gamma spectrometry. Activity concentrations of radionuclides found in materials associated with this industrial process are presented as well as the results of the assessment of the annual effective doses to the workers and the members of the public [5]. 
Stages of the process in the zircon sand processing unit to obtain or produce zirconium oxychloride that is zircon sand melted with caustic soda, the melting results are leached with water that will produce residues. Residues of water leaching are dried and then leached with hydrochloric acid with a certain comparison to take the element zircon, filtrate obtained to produce zirconium oxychloride octahydrate $\left(\mathrm{ZrOCl}_{2} 8 \mathrm{H}_{2} \mathrm{O}\right)$ [2]. At this stage of the process is suspected to contain radionuclide which is often called TENORM (Technologically Enhanced Naturally Occurring Radioactive Material) [2]. Therefore, certainty is needed at which stage should be inserted TENORM processing treatment so as not to be taken in the product and pollute the environment. In this case, tenorm identification is carried out in the process of zircon sand into zirconium oxychloride octahydrate, especially radionuclides U-238, Th-232, Ra-226 and K-40. Radiation exposure mainly occurs in the production process of zirconium oxychloride, resulting in potential radiation health hazards for workers in the production company zirconium oxychloride [2].

Radionuclide in TENORM is derived from primordial radionuclide decay from the decay of U228, Th-232, and K-40. TENORM problems should get serious attention, because it can pollute and poison the environment and interfere with public health. Coordination of handling NORM and TENORM in Indonesia is an activity involving government agencies (BATAN, BAPETEN, DEPKES, BAPEDAL, related departments), NGO, and scientists / academics.

This study was conducted with the aim of knowing the concentration of activities on TENORM in zirconium oxychloride octahydrate $\left(\mathrm{ZrOCl}_{2} 8 \mathrm{H}_{2} \mathrm{O}\right)$ results of $\mathrm{HCl}$ leaching process against sodium zirconate $\left(\mathrm{Na}_{2} \mathrm{ZrO}_{3} 8 \mathrm{H}_{2} \mathrm{O}\right)$ from zircon sand melt that accommodates radioactivity environment data in the framework of occupational safety for employees. TENORM radioactivity results, especially radionuclide U-238, Th-232, Ra-226 and K-40, can provide information for workers involved in zircon sand purification peroses, so it is expected that the work / employees carefully in acting to start a job, or follow existing work procedures.

\section{Materials and Methods}

\section{Materials}

Gamma spectrometry (Ortec Brand), HPGe detectors (Ortec Brand), Genie 2000 software, vials, analytical scales (Sartorius BSA224S-CW), sieves, and homogenizers.

The ingredients used in this study are: zircon oxychloride $\left(\mathrm{ZrOCl}_{2} 8 \mathrm{H}_{2} \mathrm{O}\right)$ result of $\mathrm{HCl}$ leaching process against sodium zirconate $\left(\mathrm{Na}_{2} \mathrm{ZrO}_{3} 8 \mathrm{H}_{2} \mathrm{O}\right)$ from zircon sand melt, Standard Reference Material (SRM) IAEA 315 Radionuclides in marine sediment as detector efficiency controller, and EU-152 as determination of energy calibration and efficiency

\section{Methods}

Sample Preparation

The solids sample of zirconium oxychloride is sifted with a sieve of 100 mesh then homogenized. $70 \mathrm{~g}$ samples of zirconium oxychloride $\left(\mathrm{ZrOCl}_{2} 8 \mathrm{H}_{2} \mathrm{O}\right)$ put in polyethylene vials, closed tightly, and stored in a certain place at room temperature for approximately 30 days to achieve radionuclide equilibrium. The sample is ready to be identified tenorm content using gamma spectrometry technique.

\section{Sample Measurement}

The sample is placed on a gamma spectrometer detector with an counting time of 86400 seconds, the measurement is done with 4 (four) repetitions. After that, the calculation of the results of the enumeration is carried out. To determine the content of radionuclide use the equation (1).

$$
\begin{aligned}
& A \gamma=\frac{\mathrm{CS}_{\gamma}-\mathrm{CB}_{\gamma}}{E \cdot P y \cdot L} \\
& \text { within : } \\
& \mathrm{C}_{\mathrm{S} \gamma}=\gamma \text { radionuclide count rate }(\mathrm{cps}) . \\
& \mathrm{CB} \gamma=\gamma \text { radionuclide blanks count rate }(\mathrm{cps}) \\
& \mathrm{L}=\text { sample weight }(\mathrm{kg}) . \mathrm{E}=\text { efficiency }(\%) \text { and } \mathrm{Py}=\text { Probability }(\%)
\end{aligned}
$$

\section{Determination of Uncertainty}

When estimating measurement uncertainty, all important components of uncertainty in an existing situation must be taken into account using the appropriate analytical methods $[12,13]$. Sources of cause for uncertainty include, (but do not need to be limited to) the standards of reference and reference materials used, the methods and equipment used, environmental conditions, the nature and condition of the goods tested or calibrated, and the operator. 
Estimates each component of uncertainty so that it is equivalent to a standard deviation according to the fault factor. Factors to be aware of the stages of sample preparation, calibration, probability of radionuclide, detector efficiency, sample counting.

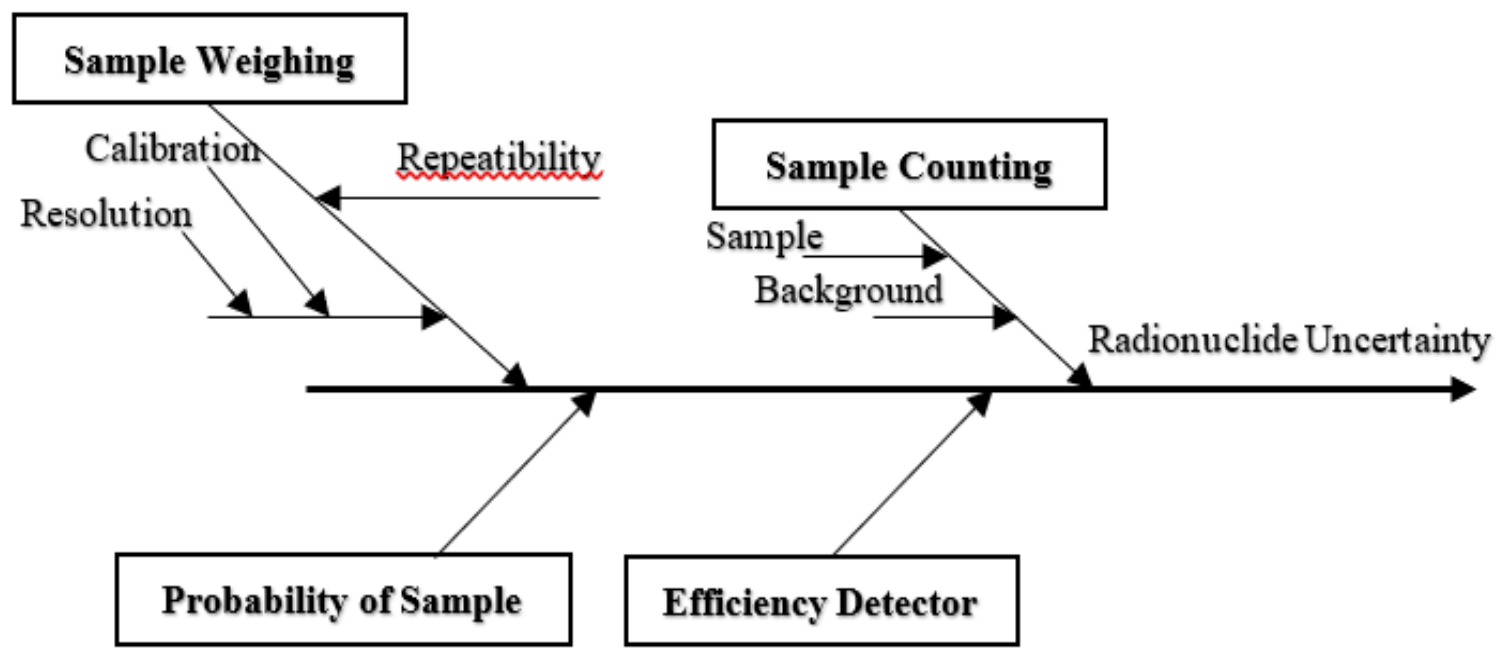

Figure 1. Cause and effect diagram (fish bone) on determining uncertainty by absolute method.

\section{Result and Discussion}

Identification of natural radionuclides (TENORM) of $\gamma$ transmitters contained in samples for qualitative and quantitative analysis using equations (1). In Table 1 the tenorm quantity identified by gamma spectrometry method is Ra-226, Pb-214, Bi-214, Ac-228, Pb-212, Bi-212, T1-208 and K-40. The radionuclide has different concentrations of activity although the difference is not inconspicuous with 4 (four) times the measurement and the standard deviation (SD) which is then used for estimated uncertainty. The measurement of TENORM radioactivity contained in zirconium oxychloride in Table 1 determines the concentration of radioactivity activity or radioactivity U-238, Th-232 and Ra-266. This is because U-238 and Ra-266 are measured based on the average radionuclide radioactivity of $\mathrm{Pb}-214$ and Bi-214 while Th-238 is measured based on radionuclide Pb-212 and Ac-228 [10,11,14].

Radionuclide Ra-226 can be determined in 2 (two) ways, namely at the peak of characteristic energy of $186.2 \mathrm{keV}$ with probabilities of $3.28 \%$, but can be interfered with the presence of radionuclide U-235 with characteristic energy of $185.7 \mathrm{keV} \mathrm{[16],} \mathrm{the} \mathrm{concentration} \mathrm{of} \mathrm{Ra-226} \mathrm{activity} \mathrm{is} 11.67 \mathrm{~Bq} / \mathrm{kg}$ presented in Table 1. While the second way to determine radionuclide Ra-266 through the estimated concentration of average activity of two peak photons from Pb-214 (at characteristic energy 295.2 and $351.9 \mathrm{keV}$ ) and three peak photons from Bi-214 (at characteristic energy $609.3 ; 1120.3$ and $1764.5 \mathrm{keV}$ ) $[10,13,14]$ and obtained a concentration of Ra-266 activity of $11.40 \mathrm{~Bq} / \mathrm{kg}$ presented in Table 2 . The results of radionuclide measurement $\mathrm{Ra}-266$ in the first way or the second way have an insignificant difference.

Radionuclide U-238 can be measured directly at characteristic energy of $48.0 \mathrm{keV}$ with a probability of $0.075 \%$ [15]. This cannot be done because it is adjacent to the $46.5 \mathrm{keV}$ energy of radionuclide $\mathrm{Pb}-210$ with a higher probability of $4.0 \%$. In Table 2 the measurement results of U-238 based on decay's average radioactivity ( $\mathrm{Pb}-214$ and $\mathrm{Bi}-214)$ on characteristic energy were $295.2 \mathrm{keV}$ and 609.3 $\mathrm{keV}$ respectively, where the concentration of measurable activity for $\mathrm{U}-238$ was $13.43 \mathrm{~Bq} / \mathrm{kg}$.

Measurement of radionuclide Th-232 based on the average concentration of activity of decay $(\mathrm{Pb}-$ 212 and Ac-228) in characteristic energy respectively $238.6 \mathrm{keV}$ and $911.1 \mathrm{keV}$, where the concentration of activity measured $12.04 \mathrm{~Bq} / \mathrm{kg}$. Radionuclide Th-232 has a characteristic energy of $59.0 \mathrm{keV}$ and has a very small probability of $0.19 \%$, such as radionuclide U-238 cannot be used directly as well as radionuclide Th-232. Potassium-40 (K-40) is determined directly at characteristic energy of $1460.7 \mathrm{keV}$, with specific activity in zirconium oxychloride $\left(\mathrm{ZrOCl}_{2} 8 \mathrm{H}_{2} \mathrm{O}\right)$ of $32.94 \mathrm{~Bq} / \mathrm{kg}$ presented in Tables 1 and 2 . 
Table 1. Results of radiaoactivity calculation and standard deviation of radionuclide in zirconium

\begin{tabular}{cccccccc}
\multicolumn{7}{c}{ oxychloride } \\
\cline { 1 - 6 } Radionuclide & $\begin{array}{c}\text { Energy } \\
\text { (keV) }\end{array}$ & \multicolumn{7}{c}{ Radioactivity, Bq/kg } & SD \\
\cline { 3 - 7 } & 186.2 & 11.89 & 12.41 & 10.50 & 11.89 & 11.67 & 0.7095 \\
$\mathrm{Ra}-226$ & 238.6 & 9.26 & 10.49 & 8.96 & 8.81 & 9.38 & 0.6611 \\
$\mathrm{~Pb}-212$ & 295.2 & 10.65 & 11.48 & 9.77 & 12.98 & 11.22 & 1.1824 \\
$\mathrm{~Pb}-214$ & 351.9 & 11.90 & 10.57 & 12.24 & 10.51 & 11.31 & 0.7747 \\
$\mathrm{~Pb}-214$ & 583.1 & 2.39 & 2.19 & 3.13 & 3.94 & 2.91 & 0.6889 \\
$\mathrm{Tl}-208$ & 609.3 & 15.48 & 15.54 & 16.50 & 15.06 & 15.65 & 0.9154 \\
$\mathrm{Bi}-214$ & 727.2 & 3.17 & 3.11 & 3.19 & 3.17 & 3.16 & 0.0300 \\
$\mathrm{Bi}-212$ & 911.1 & 15.05 & 15.90 & 14.15 & 13.70 & 14.70 & 0.8463 \\
$\mathrm{Ac}-228$ & 968.9 & 9.82 & 10.71 & 11.57 & 9.66 & 10.44 & 0.7653 \\
$\mathrm{Ac}-228$ & 1120.3 & 14.64 & 13.83 & 16.38 & 14.64 & 14.87 & 0.9311 \\
$\mathrm{Bi}-214$ & 1460.7 & 33.99 & 31.35 & 35.07 & 31.35 & 32.94 & 1.6352 \\
$\mathrm{~K}-40$ & 1764.5 & 3.65 & 4.28 & 3.65 & 4.28 & 3.97 & 0.3150 \\
$\mathrm{Bi}-214$ & & & & & & &
\end{tabular}

In Table 2 presented identification of calculated results U-238, Th-232, K-40 and Ra-266, radionuclide concentrations were $13.432 .0 \pm 0.438 \mathrm{~Bq} / \mathrm{kg}$. $12.04 \pm 1.042 \mathrm{~Bq} / \mathrm{kg}$. $32.94 \pm 1.635$. Bq/kg. $11.40 \pm 0.291 \mathrm{~Bq} / \mathrm{kg}$.

Table 2. Identify the calculated results of U-238, Th-232 and Ra-266 through its decay

\begin{tabular}{ccccccc}
\hline Radionuclide & \multicolumn{5}{c}{ Radioactivity } & SD \\
\cline { 2 - 6 } & 1 & 2 & 3 & 4 & Average & \\
\hline U-238 & 13.065 & 13.51 & 13.135 & 14.02 & 13.432 & 0.438 \\
Th-232 & 12.155 & 13.695 & 11.055 & 11.255 & 12.04 & 1.042 \\
K-40 & 33.99 & 31.35 & 35.07 & 31.35 & 32.94 & 1.635 \\
Ra-226 & 11.264 & 11.14 & 11.308 & 11.894 & 11.40 & 0.291 \\
\hline
\end{tabular}

To see the comparison of the results of radionuclide activity concentration contained in zirconium oxychloride oxidation namely radionuclide U-238, Th-232, Ra-226 from the calculation of concentration value of decay activity and Ra-226 in individual characteristic energy (186.2 keV) and K-40 activity, then made histogram comparison such as Figure 2. Visible concentration of activity almost evenly except K40 , while the lowest concentration of activity is radionuclide $\mathrm{Ra}-266$.

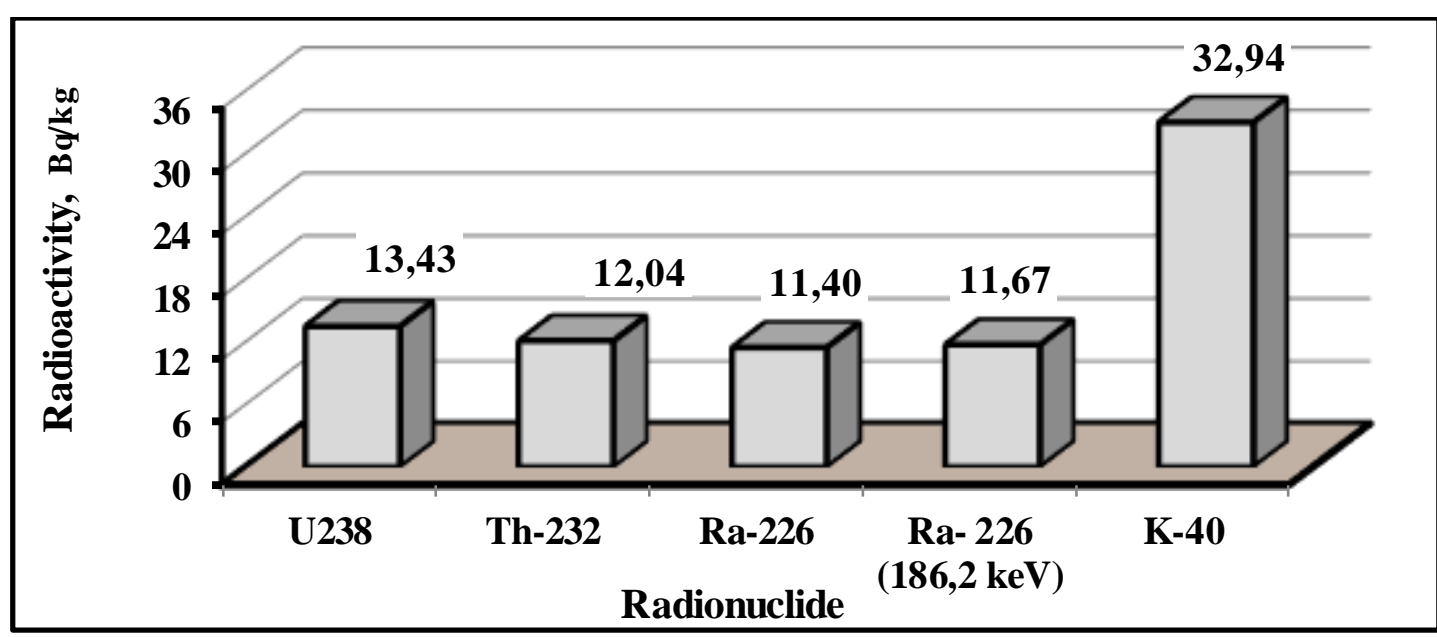

Figure 2. Histogram comparison of radionuclide activity concentrations U-238, Th-232, Ra-226 and K40 


\section{Identify uncertainties}

Drafting a model of the work step and estimating each component of uncertainty, then combining the standard uncertainty components to create the combined default uncertainty. The value of uncertainty obtained is expanded to provide an interval where the quality measured is estimated to be located and at a certain level of trust.

The uncertainty component of weighing derived from the calibration of scales, resolution, repeatability has been done previous research [13], where the influence of weighing uncertainty on the enumeration has a value of $0.79877 \mathrm{mg}$.

From Table 2 the result of activity concentration of U-238 is $13.43 \mathrm{~Bq} / \mathrm{kg}$ with the calculation statistic has a standard deviation value $(\mathrm{SD})=0.4377 \mathrm{~Bq} / \mathrm{kg}$ with a repetition of 4 times the enumeration. Correction derived from nuclear constants is the probability of U-238 derived from the child (Pb-214 and Bi-214) which is $32.645 \%$ [6], taken $5 \%$ assuming normal data distribution then the default uncertainty radionuclide U-238 is $0.008161 \%$ presented in Table 3 . From the calculation results using radionuclide Eu-152 and SRM IAEA-315 detector efficiency of $4.182 \%$ with standard deviation (SD) $=0.1976 \%$ and the standard uncertainty of detector efficiency is $=0.0988 \%$.

There are 4 (four) components that affect uncertainty in the analysis of U-238, this can be seen in Table 3, i.e. (1) sample preparation with default uncertainty value is $0.000114 \%$, (2) statistical enumeration of radionuclide U-238 with value of $3.2591 \%$, (3) probability uncertainty U-238 with niali $0.008161 \%$ and (4) detector default uncertainty with a value of $0.0988 \%$. The four components will generate combined uncertainty in the sample test (I) radionuclide analysis U-238 of $3.2606 \%$.

Table 3. Standard uncertainty in U-238 analysis of zirconium oxychloride

\begin{tabular}{ll}
\hline \multicolumn{1}{c}{ Quantity } & Standard Uncertainty \\
\hline $\begin{array}{l}\text { Sample preparation (sample weight) }=70 \mathrm{~g}=70000 \mathrm{mg} \\
=(0.79877 / 700000)^{*} 100 \%=0.000114 \%\end{array}$ & $0.000114 \%$ \\
\hline Counting statistics U-238 $=13.43$ and standard deviation (SD) $=0.4377$ & $3.2591 \%$ \\
$=\mu(\%)$ sample $=(0.4377 / 13.43)^{*} 100 \%=3.2591 \%$ & $0.008161 \%$ \\
\hline$\mu$ probability U-238 $=0.32645=(0.3265 / 2)^{*} 5 \%=0.008161$ & $0.0988 \%$ \\
\hline Standard uncertainty of detector $=0.19765 / 2=0.0988$ & $3.2606 \%$ \\
\hline Combined uncertainty (I) of sample & \\
{$\left[(0.000114)^{2}+(3.2591)^{2}+(0.0081612)^{2}+(0.09883)^{2}\right]^{0,5}=3.2606$} & \\
\hline
\end{tabular}

The combined uncertainty $(\mathrm{I})$ of the sample with a coverage factor $(\mathrm{k}=2)$ is expanded to $\mathrm{k} * 3.2606$ $=6.5212 \%$. In Table 2 the concentration of radionuclide aktvitas U-238 was $13.43 \mathrm{~Bq} / \mathrm{kg}$, with uncertainty expanded by $6.5212 \%$ equal to $0.876 \mathrm{~Bq} / \mathrm{kg}$. This indicates the concentration of radionuclide activity U-238 in zircon oxytoxyl chloride value is located between $13.43 \pm 0.876 \mathrm{~Bq} / \mathrm{kg}$. With the same step, the uncertainty for radionuclides Th-232, Ra-266 and K-40 in zircon chloride value can be known, this is presented in Table 5. Concentration of radionuclide activity, Th-232 $=12.040 \mathrm{~Bq} / \mathrm{kg}$ has an uncertainty value of $\pm 1.483 \mathrm{~Bq} / \mathrm{kg}, \mathrm{Ra}-226=11.400 \mathrm{~Bq} / \mathrm{kg}$ has uncertainty value of $\pm 0.582 \mathrm{~Bq} / \mathrm{kg}$, and $\mathrm{K}-40=32.940 \mathrm{~Bq} / \mathrm{kg}$ has uncertainty value of $\pm 3.270 \mathrm{~Bq} / \mathrm{kg}$.

Table 4. Results of calculation of uncertainty concentration of activity for U-238

\begin{tabular}{ll}
\hline Combined uncertainty (I) & $3.26016 \%$ \\
Combined uncertainty (I) expanded $2 * 3.2606=6.5212 \%$ & $6.5212 \%$ \\
Activity concentration (Radioactivity) U-238 is $13.43 \mathrm{~Bq} / \mathrm{kg}$ & $13.43 \mathrm{~Bq} / \mathrm{kg}$ \\
Uncertainty expanded $(6.5212 / 100)^{*} 13.43 \mathrm{~Bq} / \mathrm{kg}=0.876 \mathrm{~Bq} / \mathrm{kg}$ & $0.876 \mathrm{~Bq} / \mathrm{kg}$ \\
Radioactivity U-238 to $13.43 \pm 0.438 \mathrm{~Bq} / \mathrm{kg}$ & $13.43 \pm 0.876 \mathrm{~Bq} / \mathrm{kg}$ \\
\hline
\end{tabular}

Table 5. The result of calculation of radinuclide average uncertainty U-238, Th-232, Ra-226 and K-40

\begin{tabular}{lcccc}
\hline Radionuclide & U-238 & Th-232 & R-266 & K-40 \\
\hline Uncertainty, Bq/kg & 0.876 & 1.483 & 0.582 & 3.270 \\
\hline
\end{tabular}

Uranium (U-238) and thorium (Th-232) are undesirable filthy elements in the processed zircon sand into zirconia, so it is expected that U-238 and Th-232 in the process results no longer exist or with a small concentration value. The radioactivity values of U-238 and Th-232 in zirconium oxychloride when converted to heavy concentrations are shown in Table 6 . Table 6 shows the conversion from Bq $/ \mathrm{kg}$ to $\mathrm{ppm}$ or $\mathrm{mg} / \mathrm{kg}$, to U-238: $1 \mathrm{ppm}=25 \mathrm{~Bq} / \mathrm{kg}$ and Th-232: $1 \mathrm{ppm}=8 \mathrm{~Bq} / \mathrm{kg}[16,17]$. The International Atomic Energy Agency (IAEA) through technical document 390 provides a conversion factor of potassium-40 radionuclides $(\mathrm{K}-40): 1 \mathrm{ppm}=131 \mathrm{~Bq} / \mathrm{kg}$ [18]. The result of conversion of radiactivity into 
weight concentration can be seen in Table 6 , where U-238 $=13.43 \pm 0.876 \mathrm{~Bq} / \mathrm{kg}$ equivalent to $0.54 \pm 0.02$ $\mathrm{mg} / \mathrm{kg}, \mathrm{Th}-232=12.040 \pm 1.483 \mathrm{~Bq} / \mathrm{kg}$ equivalent to $1.51 \pm .01 \mathrm{mg} / \mathrm{kg}$, and $\mathrm{K}-40=32.94 \pm 1.63 \mathrm{~Bq} / \mathrm{kg}$ to $0.25 \pm 0.02 \mathrm{mg} / \mathrm{kg}$.

Table 6. Radioactivity value and concentration U-238 \& Th-232

\begin{tabular}{ccccccc}
\hline \multirow{3}{*}{ Radionuclide } & \multicolumn{3}{c}{ Radioactivity, Bq/kg } & \multicolumn{3}{c}{ Concentration, mg/kg } \\
\cline { 2 - 7 } & $\mathrm{U}-238$ & $\mathrm{Th}-232$ & $\mathrm{~K}-40$ & $\mathrm{U}-238$ & $\mathrm{Th}-232$ & $\mathrm{~K}-40$ \\
& $13.43 \pm 0.87$ & $12.04 \pm 1.48$ & $32.94 \pm 1.63$ & $0.54 \pm 0.02$ & $1.51 \pm 0.01$ & $0.25 \pm 0.02$ \\
\hline
\end{tabular}

\section{Conclusion} as follows:

From the results of identification and calculation obtained, it can be obtained several conclusions

1. Identification of TENORM contained in zircon oxytoclide $\left(\mathrm{ZrOCl}_{2} \quad 8 \mathrm{H}_{2} \mathrm{O}\right)$ by using gamma spectrometry namely radionuclide U-238, Th-233, Ra-226 and K-40. After going through the calculation of activity connotations and estimated uncertainty can be determined the results of radionuclide in $\mathrm{ZrOCl}_{2} .8 \mathrm{H}_{2} \mathrm{O}$, namely radionuclide $\mathrm{U}-238$ has a concentration of activity of $13.43 \pm 0.876 \mathrm{~Bq} / \mathrm{kg}, \mathrm{Th}-238=12.040 \pm 1.483 \mathrm{~Bq} / \mathrm{kg}, \mathrm{Ra}-266=11.400 \pm 0.582 \mathrm{~Bq} / \mathrm{kg}$ and $\mathrm{K}-40=$ $32.940 \pm 3.270 \mathrm{~Bq} / \mathrm{kg}$.

2. Radioactivity values U-238 and Th-232 in zircon oxidation chloride when converted into heavy concentrations to U-238 $=0.54 \pm 0.02 \mathrm{mg} / \mathrm{kg}$ and $\mathrm{Th}-232=1.51 \pm 0.01 \mathrm{mg} / \mathrm{kg}$.

\section{Acknowledgement}

The author thanks DIPA PSTA BATAN 2020, Mr. Sukirno, ST, Sri Murniasih, M.Sc and all parties who have helped so that this research can be completed.

\section{References}

[1] Z. Mashrur, Z. K. Mohammad, R. Mohammad, D. Farah, Presence of uranium and thorium in zircon assemblages separated from beach sands of Cox's Bazar, Bangladesh, Journal of Science, Technology, \& Environment Informatics 03 (01) (2016) 161-169.

[2] A. M. J. Nurrul, S. K. Kok, H. M. Nor, A. W. Y. Mohd, M. F. Syazwani, Malaysian monazite and its processing residue: chemical composition and radioactivity, Journal of Radioanalytical and Nuclear Chemistry 322 (2019) 1097-1105.

[3] X. Shoulong, W. Qifan, L. Xiaogang, Y. Feng, and T. Liangying, Radionuclide transfer in the zirconium oxychloride production process and the radiation effect in a typical Chinese enterprise, Sustainability 11 (21) (2019) 2-9.

[4] L. Zhao, X. Liu, W. Zhao, Analysis on radiation environment of a zircon sand dressing and processing enterprise, Environment Development 31 (2019) 21-22.

[5] R. Serena, B. Luigi, A. Massimo, Assesment of the radiological impacts of zircon sand processing plant, Journal of Environmental Radioactivity (2005) 1-25.

[6] Sajima, Pelindian natrium zirkonat menggunakan asam klorida secara catu, Eksplorium 39 (1) (2018) 67-74.

[7] Yuhelda, A. Dessy, P. N. Enggan, Processing zirconia through zircon sand smelting with $\mathrm{NaOH}$ as a flux, Indonesia Mining Journal 19 (1) (2016) 39-49.

[8] S. Endang, Pembuatan $\mathrm{Zr}\left(\mathrm{SO}_{4}\right)_{2} \cdot \mathrm{xH}_{2} \mathrm{O}$ melalui jalur zirconium basic sulphate (ZBS) sebagai umpan pada continuos annular chromatography (CAC), Jurnal Teknologi Bahan Nuklir 9(2) (2013) 55-113.

[9] B. Aziz, B. Laila, A. Khadija, N. Hamid, B. Mohammed, N. Abdelmjid, Measurement of natural radioactivity and radon exhalation rate in coal ash samples from a thermal power plant, World Journal of Nuclear Science and Technology (6) (2016) 153-160.

[10] N.M. Ismael, M. N. Mungubariki, K. M. Najat, Assesment of radioactivity levels in coal and coal ash in Kiwira coal mine using gamma-ray spectrometry, Tanzania Journal of Science 44 (3) (2018) $1-11$.

[11] R. C. Romala, V. M. Chobey, D. G. Prasad, A. Kies, Radionuclide analysis in the soil of Kumaum Himalaya, India using gamma ray spectrometry, Current Science 100 (6) (2011) 906-914.

[12] Q. Can, Y. Huanfang, H. Caixia, Certification and uncertainty evaluation of flavonoids certified reference materials, Agricultural Sciences 4 (9B) (2013) 89-96.

[13] Sukirno, Samin, Estimasi nilai ketidakpastian analisis radionuklida Ra-226, Ra-228, Th-228 dan K40 dalam cuplikan sedimen dengan teknik spektrometri gamma, Jurnal Iptek Nuklir GANENDRA 14 (1) (2011) 10-18. 
[14] Sukirno, M. Sri, Rosidi, W. W. Sutanto, Radioaktivitas alam hasil pembakaran batubara dari PLTU Pacitan, Prosiding PPIPDIPTN PSTA- BATAN Yogyakarta (2016) 70-74.

[15] G. E. Von, S. Werner, The Gamma rays of the Radionuclides, Verlag Chemie: Weinheim, New York, 1979.

[16] World Nuclear Association Mineral Sands, NORM Appendix 1, England and Wales, London, 2013.

[17] I.I. Mohd, S. K Kok, M. F. Syazwani, Measurement of ${ }^{238} \mathrm{U}$ and ${ }^{232} \mathrm{Th}$ radionuclides in ilmenite and synthetic rutile, IOP Conference Series Materials Science and Engineering 298 (2018) 1-6.

[18] B. M. Felix, M. Paulus, D. M. Risimati, M. Peane, Determination of uranium and thorium concentration and gross alpha and beta activity measurement in top soil samples from Richards Bay, South Africa, Journal of Radiation Research and Applied Sciences 11 (2018) 305-310. 